\title{
WEST(ERN URBANISM):
}

\section{A PART OF SOCIAL FANTASY SPACE}

\author{
A B S T R A C T
}

New Belgrade represents one of the most intensively built and criticized settlements of the socialist Yugoslavia. Its contemporary criticism is shaped, like most of Serbian architectural historiography, by a belief in the clear distinction between selfness and otherness, contemporariness and outdatedness. The question of a contemporary approach is set, within this discourse, as a matter of the ability or will to see clearly the development of the Other, in whose reflection one's own development (through the elimination or acquisition of inner Otherness) can flourish.

This paper is dedicated to the exposure of the essential limitation of these distinctions. By pointing to the way that the West and western urbanism were envisioned within three moments of New Belgrade socialist history, this paper tends to point out that these visions are nothing more but parts of a wider Lacanian social fantasy space, i.e. that the realism of their gaze is based on the possibility of a placement within the fantasy space of the current or desired social order. 


\section{INTRODUCTION}

New Belgrade was founded in 1946, as a new socialist city, the capital of newly-founded socialist Yugoslavia. Although the capital-city concept was changed several years later, in accordance with the current procedures of decentralization ${ }^{1}$, New Belgrade kept a special distinction in relation to the other settlements developed by socialist urbanization. This distinction can be examined through the presence of the investors "with special needs"', but also through the social structure of New Belgrade residency, dominantly employed in "sectors which", at the time, "designated relative success in social promotion, and better economical and safer social status" " within the structure of Yugoslav society.

Although New Belgrade was most intensively built and criticized throughout the period when the official Yugoslav social concept was socialist selfmanagement $t^{4}$, which implied promotion and development of selfness, from self-determination ${ }^{5}$ of each individual to self-orientation ${ }^{6}$ of each nation that formed Yugoslavia, procedures of defining and criticizing New Belgrade were constantly influenced by appearances of otherness.

This relationship between selfness and otherness is defined by contemporary Serbian architectural and urban historiography, among other ways, through treatment of the term contemporariness ${ }^{7}$. Contemporariness is defined, either as periodical waves of "Europeanization" of Serbian architecture, which represent only an introduction to (more valuable) "national Avant-garde periods", or merely as a question of "remaining abreast of global developments", which is also viewed as a "typical trademark of Serbian architects". . Furthermore, contemporariness is frequently perceived through the perspective of architectural and urban development, which is defined as western ${ }^{10}$.

The common thread of these approaches, regardless whether they date from the period of Yugoslavia's existence, or after its demise, is certainly the tendency to judge the contemporariness of one's own architecture and urbanism through the existence of real world-wide developments, i.e. that contemporariness itself is viewed as a question of the ability or will to register these developments ${ }^{11}$.

In some cases, which are linked to New Belgrade criticism, contemporariness even represents an effective way of distancing parts of architectural profession (dedicated to the principles of CIAM urbanism), which are dubbed ideological or out-moded, from remaining parts of the profession, whose approach is 
defined as scientific (post-ideological) and consistently aware of the current development of contemporary architectural theory and practice ${ }^{12}$. In that sense, the opposition ideological vs. scientific can be viewed as an opposition between rigid, enclosed, out-moded and flexible, opened and contemporary.

Today, when New Belgrade is encompassed by an intensive process of space "commodification", which finds its roots in the actions of Serbian architectural profession (or parts of it above described as consistently contemporary) just before the collapse of Yugoslavia ${ }^{13}$, a question is raised concerning the way that the rejection of CIAM urbanism was produced, while the potential connection of this rejection with "post-socialist" 14 tendencies of Yugoslav late socialism remains a particularly important one.

By examining the ways of defining, carrying out and criticizing New Belgrade urbanism (through competition projects, urban studies and texts in professional magazines and publications) throughout the period of socialist Yugoslavia, this paper tends to point out a significant limit of the distinction between contemporary and out-moded, in the perspective of the reality of West's existence. The study of New Belgrade settlement's history is directed toward the exposure of the West(ern urbanism) as only a part of wider social fantasy. This exposure is arranged around three moments: the professional public debate on questions of architectural and urban development during the 1947-1948 period, in the Zagreb magazine Arhitektura, the criticism of modernist urbanization in the second half of the 1970s, dedicated to the formation of the Socialist City, in Yugoslav sociological and architectural magazines, and the promotion of (New) Belgrade national culture renewal project Središte kulture III milenijum, in the period of the second half of the 1980s.

The selection of these moments has been guided by the fact that each one of them is dedicated, at some level, to the question of the presence of a western element, in the context of one's own social development (urbanization included). It is just this special treatment of the western element (the inner otherness), whether as a left-over of preexisting era of Capitalism, or as an imported element, or else as an enlightened element of the Serbian society, that defines the western as an "element which sticks out", because of which the examination of this element as a part of fantasy space becomes most significant ${ }^{15}$. In that sense, the research of these three moments of New Belgrade's history will be directed toward questioning of "false tautological" relation between the West as "series of effective properties" and western (urbanism) as that which is "in object more than the object"16. 
This treatment of West and western elements is presupposed as a key factor of defining (during the late 1940s) and challenging (during the late 1970s and the early 1980s) the New Belgrade urbanism, and its modern roots. At the same time, these relations are presumed as the basis of the application of traditional urban forms, within the tendency toward the cultural renewal of Serbian capital, i.e. Belgrade, during the 1980 s.

Fantasy, in that sense, is not presumed as a question of a distorted version of reality, but just the opposite, question of West's reality is presumed as directly connected to the possibility of identifying this "reality" with a "certain place in the symbolic fantasy space" ${ }^{17}$. Fantasy, as such, is treated as a kind of a compromise structure, "an image set to work in signifying structure", an element of protective structuring of reality, of covering a split, or $\operatorname{lack}^{18}$, while the functioning of a fantasy is presumed as a "filling of a relationship which does not exist", between selfness and otherness, i.e. as a way of "bestowing on it" (the nonexistent relationship) "the fantasmatic consistency"19.

\section{WEST IN CRISIS}

The conflict between Yugoslavia and the Soviet Union in 1948 represents one of the key events in postwar Yugoslav history. This act of "pure refusal", which will later be given positive form through the "ideological project of self-management" 20 , was interpreted by some key theoreticians of this project (Edvard Kardelj included) as a result of "different approaches to the question of internal development of Yugoslavia and the USSR", ${ }^{21}$ which marked the period that preceded the conflict with Stalin as the place of its origin.
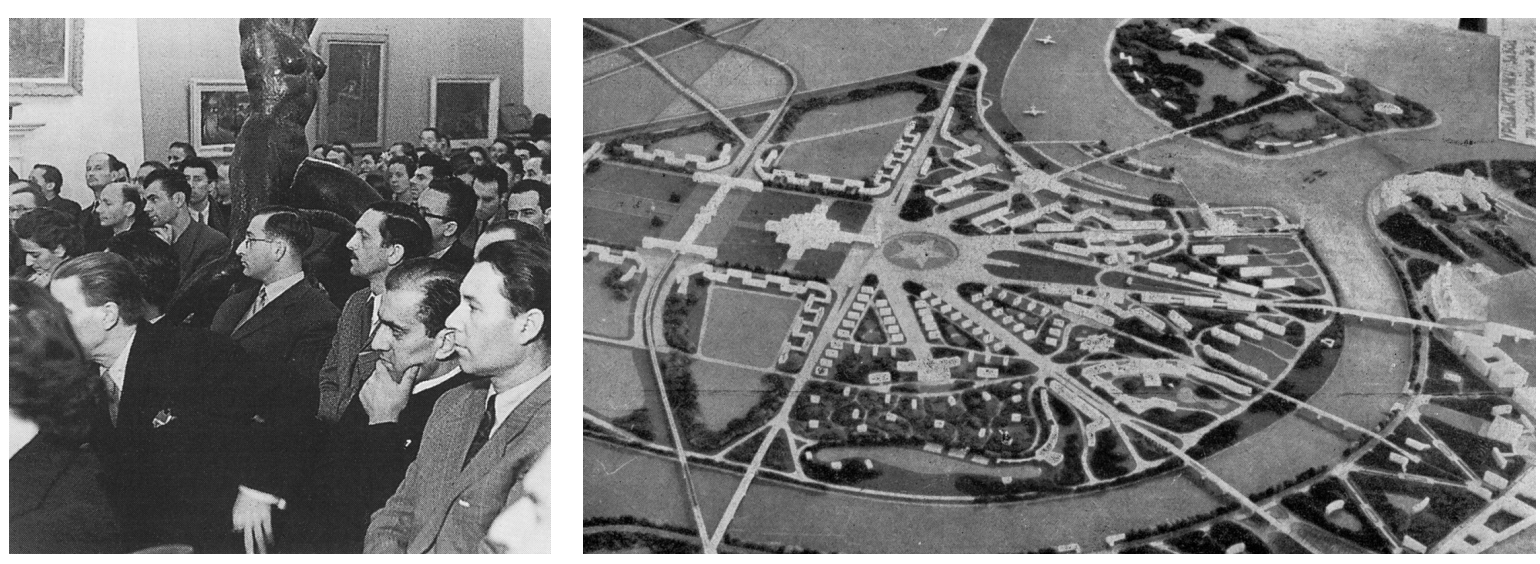
A similar relationship toward the presumed root of the 1948 conflict was developed within the so-called "dubrovačko savetovanje"22 (Fig. 01), a Yugoslav architectural congress held in 1950. The question of abandoning the "collectivistic approach" 23 to architectural creation was singled out within the proceedings as a key way of distancing from the existing negative professional tendencies, while at the same time this abandonment was viewed also as a way of escaping the abyss of Soviet architecture. The congress, nevertheless, remained quite vague in relation to a split existing within the Yugoslav profession on the issue of a way the work of early $20^{\text {th }}$ century Avant-garde movements and their connection to the social framework of Capitalism should be treated. This issue was particularly developed on the pages of the Zagreb magazine Arhitektura, which was the place of an intensive, 1947-1948 debate on the future direction of Yugoslav architectural development. The question of New Belgrade development was a particularly important part of discussion, given the fact that this was the space of the future federal capital, the space with "federal significance" 24 .

The bulk of the discussion was positioned within the wider context of global events in architectural and urban profession, with the emphasis on the connection / distance of the Yugoslav and Socialist tendencies to / from the principles of modern (functionalistic, new, contemporary) architecture and urbanism. In one of his Arhitektura articles $^{25}$ Neven Šegvić defines his analysis of the connection between Capitalism and Modern movement through the study of the "bourgeois architecture" 26 , which is namely a direct superstructure of capitalist social framework. Based on "wrong, unarchitectural and unsocial presumptions", bourgeois architecture represents a creation that is "without ideas and without principles" ${ }^{27}$. The bourgeois architecture formalism, developed in two directions, "functionalism and constructivism", is for Šegvić a signal of the absence of "creative and architectural elements" 28 - the absence which is an effect of positioning the work of architecture in the service of the Bourgeoisie, or the taste of individual ${ }^{29}$.

Pointing out the fact that there can not be a harmonious architectural development within a class-bound society, and while advocating the unity and balance of basic elements (form, function and structure), Šegvić claims that the root of bourgeois architecture crisis is in the conditions of the Capitalism itself and states:

'This crisis is the result of inner weaknesses of Capitalism, of its inner oppositions, of which architecture is also the result." ${ }^{30}$ 
As such, bourgeois architecture is considered inadequate to the socialist project. Šegvić's article is based, beside the assumption that functionalism and constructivism are direct products of Capitalism, also on the assumption of the crisis of the West (as in Capitalism), because of which the result of bourgeois architecture is treated as merely a matter of a vanishing moment:

"The inability to achieve unity of capitalist epoch architecture is not an accidental happening; it is strictly connected to the structure of Capitalism, as we have stressed at the very beginning. This unity will be found in Socialism, which we have already entered after the USSR, and which the whole world will enter soon, because it is an inevitable course of History." 31

The insistence on the connection between Western functionalism, but also on Soviet constructivism, and capitalist social system and its crisis represents an almost universal attitude of architects who demanded rejection of modern architecture and urbanism and development of architecture that would be "national by form and socialist by contents" 32 . The demands for the "elimination of old Yugoslavia capitalist remains" 33 from the framework of Socialism were defined in this sense, and modeled after the similar process in the Soviet Union. The years after the Soviet Revolution were treated as a period in which capitalist remains still existed (in the form of constructivism), while the same were considered eliminated by the "development of architecture on solid and healthy grounds" 34 , in the 1930s.

The New Belgrade urban proposal, which was a part of the 1947 competition sheets $^{35}$ designed by The Urban Institute of Serbia, can be viewed as an alternative to the bourgeois architecture and urbanism. Organized through the fan-shaped communication grid, the design is best recognizable by the socialist five-pointed star, inscribed within the central square (Fig. 02). The criticism of the design's inherent formalism by Josip Seissel ${ }^{36}$ points to the simultaneous existence of an option which can be viewed as an alternative to the abovedescribed criticism of the western Avant-garde, an option whose attitudes were directed toward the correction of a belief that the same can be seen as a direct product of Capitalism.

An article ${ }^{37}$ by Mira Krajger, which starts with a claim that a theoretical insight into all of problematical positions of contemporary architecture (including the one "that originates from the West" ${ }^{38}$ ) is needed, can be seen as an attempt to legitimize a more pragmatic approach to western architecture. By refusing 
an a priori attitude toward the unbreakable bond between modern architecture and capitalism, Mira Krajger states that it is necessary 'to come out of the generalizing position dedicated to the remains of Capitalism in the context of Yugoslav architecture" ${ }^{39}$. In that sense, by referring to the positions of Friedrich Engels, Mira Krajger states:

"It is without doubt that it cannot be claimed that all that originates in the West, in the field of arts, is decadent and formalistic, architecture included. Indeed, the position of an honest architect is even more difficult than the position of other creative departments, because he cannot find full pleasure in his work, if his projects are not realized." ${ }^{40}$

The compassion of Mira Krajger toward the experiences of western architects can be viewed as a variation of Milorad Macura's positions, defined in an article ${ }^{41}$ published in one of the previous numbers of Arhitektura, and dedicated to the competition works for the Federal Government headquarters in New Belgrade. Macura states that architecture is a form of superstructure (conditioned by socio-economic base) and that "loans are conducted in the absence of one's own values" ${ }^{\prime 2}$. Macura accuses capitalist society of being incapable of defining its own architectural framework (with its own "artistic" 43 values) and forced to borrow the forms of collapsed feudal aristocracy, as can be recognized in some Belgrade examples ${ }^{44}$. Pointing to the sameness of contemporary socialist directions and the making of "revolutionary, new directions" in urbanism, Macura states that the new urbanism (marked by a dedication of space to common good) is essentially opposed to the principles of capitalist system.

The key position of Macura's article can be traced to the claim that capitalist society, because of this opposition, "could not accept" 45 the new urbanism. It is just this claim that will make the most influence on the future development of CIAM urbanism in socialist, post-1948 Yugoslavia, because it would imply that only in socialism, i.e. the progressiveness of existing social relations ${ }^{46}$, it is possible to develop the new urbanism. As a way of resolving "the double negation of simultaneous rejection of paradigmatic models" ${ }^{47}$ of the East and the West, this attitude ensured opening toward the works which were defined by critics of western Avant-garde as decadent and capitalistic.

Can we view, in light of previous description, the two existing options of judging the relation between modern architecture / urbanism and capitalism, as the opposite? The thing that connects two previously described options is that in an attempt to create an adequate superstructure ${ }^{48}$ of existing social relations, both options interpret existing socialism as extremely progressive. 
The connection between these options can also be viewed through the common examination of western architecture as a transparent entity through which it is possible to read all the decadence and repressiveness of Capitalism, but also to define the progressiveness of Socialism. At the same time, there is more to the western (bourgeois or capitalist) architecture than the mere symbolization of Capitalisms repressiveness. The same is an embodiment of that which is "in object more than the object" ${ }^{49}$, i.e. that which is in West more than West, of enjoyment (architectural / creative $\mathrm{e}^{50}$ or $\operatorname{artistic}^{51}$ ) allegedly stolen from architects, and other working people, by the Bourgeoisie. Further more, the interpretation of the West (Capitalism) as decadent belongs to the same fantasy space as the definition of Socialism as a highly progressive system, through which the (stolen) enjoyment will be placed properly, or used to the common good.

The elimination of capitalist remains, the "foreign body" that "cannot be integrated into the existing social order" becomes a matter of priority because it designates the direction toward the complete fulfillment of Yugoslav socialism. This foreign body can be seen as an outward projection of an inherent impossibility of Yugoslav socialism itself, i.e. the "positive condition of its existence" ${ }^{52}$. In that sense, the thing that could serve as a signal of Socialism's impossibility, the nonexistence of one's own, Yugoslav and Socialist architecture and urbanism (and the search for the means of identifying the same with the architecture of the West or the East), is transformed through the criticism of post-WWI Avant-garde as adequate / inadequate to the goals of Socialism into an actual proof of Socialism's existence.

The compassion of some Yugoslav architects toward the difficulties of their western colleagues plays an extremely important role in this fantasy scenario, because it pacifies the early $20^{\text {th }}$ century Avant-garde, making it, in a way, the same as Yugoslav profession. Just as Yugoslav profession, the Avant-garde is a progressive entity denied the enjoyment, an entity that can be tolerated, because the "intolerance to the Other is the intolerance to Other's enjoyment" 53 .

Furthermore, the vision of the Yugoslav Socialism as progressive social system, capable of developing contemporary tendencies, even those that originated in the West, proved as extremely performative ${ }^{54}$, in the sense of defining a new cultural model ${ }^{55}$. The same involved the examination of the emerging forms of jazz and adventure novel, as can be seen in the Edvard Kardelj speech during the Third Congress of the Serbian League of Communist, in which he states, while rejecting "Stalinist enclosure from the world" ${ }^{\text {, }}$, the following: 
"I would return to the question of our peoples cultural pastime. Chaos has evolved there, and with it some damaging tendencies, because of the narrow minded approach of many communists to this area of life... It seems to me that it is the most important for us to give encouragement to one's own cultural creation even in that field. It seems to me that entertainment needs to be basically healthy, humanly pure, at a certain elementary cultural level, and jazz and adventure novel can also be that. ${ }^{57}$

\section{WESTERN SABOTAGE}

One of the results of Yugoslavia's conflict with the Soviet Union in the second half of the 1940s was the intensive promotion of the new Yugoslav socio-economical concept: socialist self-management. Assumed as equally 'institutionalized and immanent" 58 , proclaimed system guarantied, not only complete realization of democracy or direct management of the means of production by workers, but also the possibility of a creative engagement by each individual ${ }^{59}$.

At the same time, the concept of self-management implied a series of factors that were defined as a threat to the realization of self-manager's creative potentials. The presence of bureaucracy was considered to be a special danger, while the tendency to eliminate "the autonomy of the bureaucratic apparatus" was frequently presented as a way of distancing Yugoslav socialism from the Stalinist model ${ }^{60}$. Strongly linked to its legitimizing framework (dogmatism ${ }^{61}$ ), the bureaucratic threat was considered similar to the one of technocracy, which was also defined as the "main danger" 62 to socialist self-management. Technocracy implied the actions of "managers who hold the executive

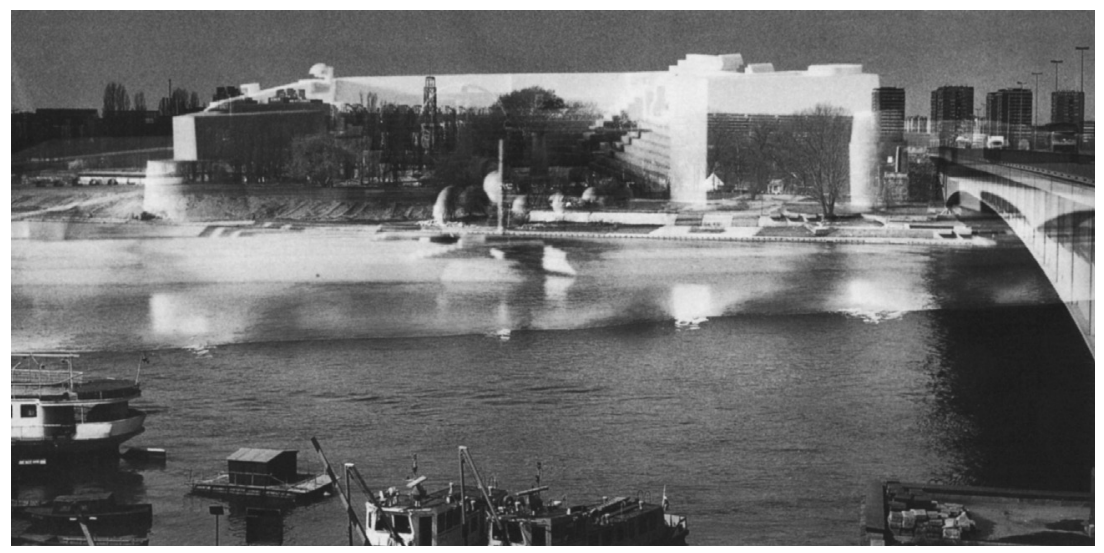


power" ${ }^{63}$, but this term also referred to various forms of professional action, architecture / urbanism included.

The criticism of bureaucratic tendencies and dogmatism was also used as a way of constructing a clear separation between the action of architectural profession during the 1950s and 1960s from the professional action during the late 1940s. Assuming the realization of the "new social climate delivered from dogmas and illusions of past times", the period of 1950s and 1960s was defined by the actors of the same period as a time when "anti-dogmatism" ${ }^{64}$ was the main trait of architectural interventions. The development of New Belgrade urbanism during the 1950s and 1960s was also placed under the guise of the same doctrine, while the transformation of the basic concept, from "management city to city of housing" ${ }^{65}$, designated the direction of future interventions most intensively conducted during the second half of 1960s and first half of $1970 \mathrm{~s}^{66}$.

At the same time, the attempts at defining a self-management concept of urban development during the 1970s and 1980s were frequently related to actions aimed at "depriving the techno-bureaucracy of power and delegating the power to the people" ${ }^{67}$. The results of socialist urbanization, New Belgrade included, were marked by younger architects as the "last remains of state-bureaucratic ideal" 68 . This logic was supplemented by "traditional urban morphology reaffirmation" process, on a series of urban projects during the late 1970s and throughout the $1980 \mathrm{~s}^{69}$, but also by 'active mobilization of architects, planners, councilmen, workers and Belgrade citizens on the urgent assignment of building the new city center" ${ }^{\prime 70}$, within the traditional city core. The revalorization of traditional urban space culminated in the second half of the 1980s with the symbolic "enclosure"
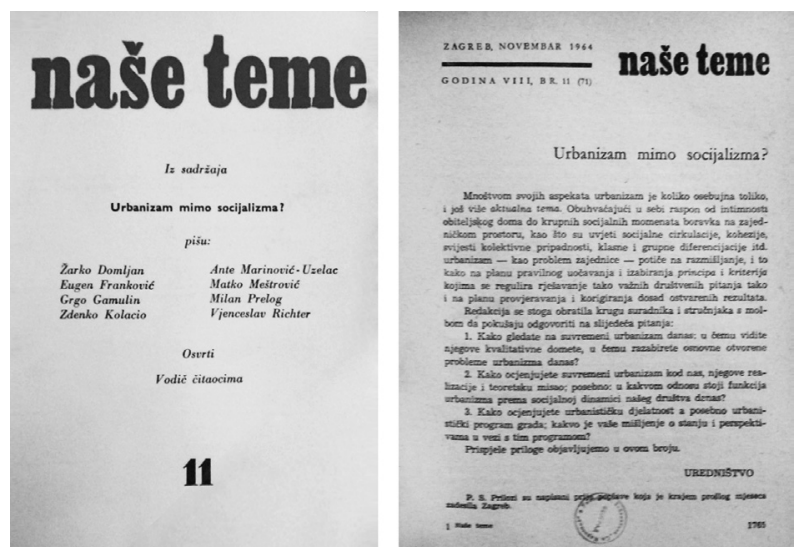
of Mihajlo Mitrović's "Sava pueblo" from the "challenged New Belgrade urban structure" and the orientation of the same to the "historical focus and the most beautiful image of the old Belgrade" 71 (Fig. 03).

While in some cases the call to eliminate bureaucratic tendencies served as a neat framework for the promotion of, to use Aleksandar Ignjatović's definition, "conceptual coherence of Serbian $20^{\text {th }}$ century architecture" 72 , i.e. the construction of national continuity with the times that preceded the formation of post-WWII Yugoslavia, in other cases the criticism of bureaucratic tendencies was consistently oriented to the research of the so-called "Socialist City" 73 . By acting on the basis of Marxist theoretical platform, primarily the works of Manfredo Taffuri and Henry Lefebvre, a series of authors (mainly sociologists) approached the problems of socialist urbanization as a question of "imported elements" 74 within the Yugoslav urbanism. This approach presumed a tendency to use the Le Corbusier urban model within the socialist urbanization, while the same was treated as a direct product of capitalist social relations, or to put it differently: as a "capitalist city"75 (Fig. 04). The failures of postwar urbanization were treated as products of a " bureaucratic-utopian rationality"76, while the actors of the debate expressed "amassment" the presence of CIAM urbanism within the framework of socialist urbanization. The relationship toward Le Corbusier, as one of the key figures of CIAM was constantly examined, as can be seen in the following, Nenad Starc's example, where the author, while criticizing the conditions of settlements such as New Belgrade, states:

"It is unclear why we considered Le Corbusier before, but also long after the war, as a city-maker whose ideas should be followed even within socialism." 78

An almost identical argumentation was promoted by some architects, among which was non-other than Milorad Macura. In one of his articles ${ }^{79}$ from the late 1970s Macura states that the current state of architectural and urban space is characterized by "essential and structural disintegration" $"$. By pointing out the fact that existing urbanism has resulted mostly in "tectonic structures which impress the observer only as an esthetical appearance" the contemporary ambient lacks just the "radiations" which, at a more modest level in the previous periods "acted perfectly"

Convinced of the "new moral and ethical values" 83 which will be the trademarks of the future Yugoslav society, Macura claims that the present state of urban environment can be explained by insufficiently integrated state of 
architectural and urban theory - theory which originated in the second half of the $19^{\text {th }}$ century, in the conditions of "'capitalist socio-economical system, in accordance with the interests of the ruling class" $" 84$. Macura explains that this approach to urban environment engulfed only "physical elements of the city, and not the essential - humane and special ones, leading to the development of oppositions originating from social reality in the new urban tissue" ${ }^{25}$. In that sense, the state of urban environment of socialist countries is explained by Macura by following:

'Maybe the disintegration of architecture is in accordance with essential, but hardly visible interests of the ruling class, within the capitalist society. Because the space of human life is a special cluster of all the states and relations which exist in the social community that creates it, the segregation of individual elements makes viewing of all the positive and negative factors of the wholeness ever more difficult. Seemingly, the scale of responsibilities and duties that originate from the existence and inescapable development of built space is made smaller.

This kind of interest is not present in socialist communities, not even in the countries that are building socialism. Disintegration of architecture in those countries is either inherited or imported with other elements of civilization, from the developed capitalist countries." ${ }^{86}$

A part of Macura's argumentation, which is dedicated to the conditions of the development of urban theory, with the accent on disintegration of urban environment and the relation of the same to the interests of the ruling class, has several significant similarities with the term "class strategy" 87 , defined by Henry Lefebvre. The concept of class strategy implies a triple activity on the production of space, in accordance with the capitalist power relations: the first phase, dedicated to the expulsion of the working class from the central area of Paris, through the help of Haussmannian reconstruction; the second phase, which is conducted in the interwar period, characterized by the segregation of housing element (habitat) from the wholeness of urban experience (to inhabit); and the third phase, of postwar development of new housing settlements, in accordance with the concept of segregating the functions and programming the everyday experience of an average worker. Class strategy can be equally applied to the current state of theory and practice ${ }^{88}$, which are treated as simultaneously segmented and complementary causes of the current state of urban environment.

At the same time, it is possible to point out a position in Macura's argumentation which cannot be located in Lefebvre's account. While linking the question of contemporary urbanization failure to the reproduction of capitalist power 
relations, just as Lefebvre, Macura goes one step further and explains the problematic of Yugoslav urbanism through attainment of western (capitalist) elements. Macura's argumentation can be seen as an attempt to 'totalize the field of meaning" moment when social negativity assumes positive existence" ${ }^{90}$.

As such, the signifier Capitalism determines simultaneously the entire complex field of relations between planning, designing, materializing and exploiting the Yugoslav urbanism, while the effectiveness of this determination can be viewed through the framework of the same mechanism, as in the previous fantasy. Just as the previous fantasy, this one is also based on the assumption that the western element (this time imported, while previously it was inherited) is present within Yugoslav urbanism, and that the same must be neutralized in order to advance further on the road to Socialism. This form of the excess (previously remains) plays a double role: it links the negative moment of socialist urbanization to the western element, while at the same time it transforms this negative moment into the positive moment of selfness, turning it into a plane onto which the Yugoslav road to socialism is reflected as a difference. The element that guaranteed the reproduction of power relations in Capitalism, becomes in Socialism the element which prevents the enclosure of the social as a totality, or to put it differently, the enjoyment which Macura relates to the radiations that acted perfectly in the past becomes lost through the socialist urbanization thanks to the presence of an element that cannot be integrated into the existing social system.

The most effective part of this fantasy can be related to its ability to provide further consistency to the ideological project of self-management. While returning to the image of the modern urbanism as a capitalist product, it leaves unchallenged the very field of "Socialism's historical victory"'. Further more, we can view Macura's intervention (just as the one of the Socialist City theoreticians), as ideological, in the sense that ideology is most effective "when the facts that at first contradict it" (the contradiction of the presence of capitalist city within Socialism), begin to "'act in its favor" $" 92$.

\section{WEST, AS A REALITY}

The criticism of postwar urbanization by architects and planners dedicated to further legitimization of the "struggle for Socialism"93 became throughout the 1980s increasingly a matter of isolated events. Throughout this period, architectural and urban profession conducted an intensive distancing of its discourse from the official ideology of self-management, while constructing 
a "seemingly apolitical"94 general stance. This approach is most effectively explained by Vladimir-Braco Mušić, stating the following:

"Concerning the spatial reflection of our socio-developmental normative concept, self-management relations should be built first, and then we will easily deal with their reflection in the spatial structure. To imply relations that are not reached yet would mean constructing another urbanism utopia." 95

This attitude reflects a significant change in relation to the stance of postwar modernists ${ }^{96}$, defined by Ljljana Blagojević as a twisted version of Avant-garde doctrine: a belief that the "change of social relations, and not architecture

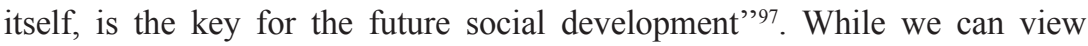
this attitude toward the social development in accordance with the Boris Groys "relinquishment of primogeniture right" 98 formula, through which the architectural profession accepts its role as just one of the groups dedicated to building of Socialism, Mušić standpoint can be seen as an attempt to create a seemingly total disjunction between architectural and ideological. The new professional position is constructed as completely separated from the framework of self-management and dedicated to the professional problematic, i.e. separated from the socially and politically engaged praxis of postwar urbanization.

Furthermore, the architectural profession generated an almost complete absence of criticism directed toward the political framework of socialist urbanization, while the research of the "political impact on the city planning" was conducted by a smaller part of professional public (mostly sociologists), among which was Ksenija Petovar. Petovar states, while indicating that founding and building New Belgrade was a matter of a "political decision", that it was just the political character of postwar urbanism that directed future interventions toward the representative function of urban space ${ }^{100}$.

The criticism of New Belgrade urban structure by Miloš R. Perović, which was (along with the proposition for the future New Belgrade urban structure), published in 1985 as Iskustva prošlosti ${ }^{101}$, can be viewed as an almost opposite approach to Petovar's. Defined as a challenge of the New Belgrade 1959 plan, Perović's criticism can be viewed as a climax of professional de-politisation, i.e. the construction of a new objective approach to the urban problematic.

By pointing to the structural similarities of Le Corbusier urbanism and the New Belgrade plan, Perović states that the concept of the New Belgrade central zone is an example of "implemented clichés" 102. Perović's criticism does not 
question the relationship between the official ideology and the New Belgrade urbanism, but is formed on the basis of a need for an objective, almost transhistorical approach to rebuilding New Belgrade through the use of traditional urban morphology, which is viewed as a guarantee of city-ness. In that sense, Perović extensively cites biologist Rene Dubos, including the following:

"In contrast to the use of ancient buildings and landscapes, the present tendency is to emphasize the suitability of buildings and landscapes for the economic and political aspects of life rather than to the fundamental human needs. This may provide for transient efficiency according to the modern criteria, but rarely for lasting usefulness." 103

Perović recognizes the 1959 urban project not only as a question of a 'lost sense of human scale" 104 , present in traditional urban morphology but also as a question of losing contact with the "progressive CIAM development"105. Perović divides the propositions for New Belgrade urbanization in two groups: in the first one there are the works of Nikola Dobrović from 1946 and 1948 and the Edvard Ravnikar's 1947 solution $^{106}$. In the second group there are the propositions from the $1950 \mathrm{~s}$ and $1960 \mathrm{~s}^{107}$, which are considered as inspired by "out-moded formulae of modernism" 108 , while the proof of their out-datedness is the "fact that it has been over twenty years since a serious book has been written in support of the concepts defined in the Athens Charter" 109.

This insistence on the out-modedness of CIAM urbanism can be seen as belonging to the Yugoslav architectural tendency dedicated to the discovery of a new contemporary world-wide urban doctrine, in the years that preceded the publication of Iskustva prošlosti. While Perović, as an observer, took part in the Delos meetings, which can be seen as a direct attempt of inheriting the role and significance of Athens Charter and CIAM $^{110}$, other architects directed their attention to professional charters as the "Machu Picchu" 111 declaration or the 1981 "Warsaw Declaration of the Architects of the World"112. This approach was confronted by others who, like Ranko Radović, skeptically accepted the possibility of forming a "new Athens Charter" "113, while calling for the realization of "'one's own praxis of human settlements" 114 . This approach, supplemented by a stance that it is necessary to form an "essential, Marxist, open and critical" evaluation of the city-building within "'our new community" 115 , was becoming, in the conditions of increased disavowal of socialist inheritance by seemingly apolitical architectural profession, a matter of an exception ${ }^{116}$.

Based on a need to humanize the existing structure, defined as 'Le Corbusierian city" ${ }^{117}$, Perović's proposal presumed the use of traditional urban morphology, 
through the application of the "Hippodamus urban grid" "118. The grid is combined with "focal points", among which pedestrian trajectories are formed ${ }^{119}$ (Fig. 05). One of these is the trajectory on the Federal Executive Council-train station axis, dedicated to the "large urban park with a geometrically shaped lake", whose effects are compared by the author with "walking through the Classical French gardens" ${ }^{120}$.

The proposal also presumed the formation of a city-like boulevard (existing Bulevar Lenjina street), the positioning of central urban functions along pedestrian zones and development of the remaining territory in the system of "traditional city" 121 morphology. The proposition also contains the usage of a series of "romanticizing elements", such as the new canal, the tower, the great lake on the FEC-train station axis, and the artistic colony at the Malo Ratno Ostrvo $^{122}$. (Fig. 06)

This urban proposal was supplemented through the Središte kulture III milenijum publication with architectural designs for cultural, housing and business buildings ${ }^{123}$, whose presence was viewed as a way of forming a new Belgrade cultural centre on the left and the right banks of the Sava River. The Središte kulture III milenijum project was defined as a result of an initiative by a group of members of the Serbian Academy of Sciences and Arts with the goal of "lifting the people to a higher cultural level", while the formation of a new cultural centre was viewed as a question of "utmost significance", because the same was seen as "providing the introduction to the heritage of the past and present and acquiring a sense of one's own continuity of cultural development"124.

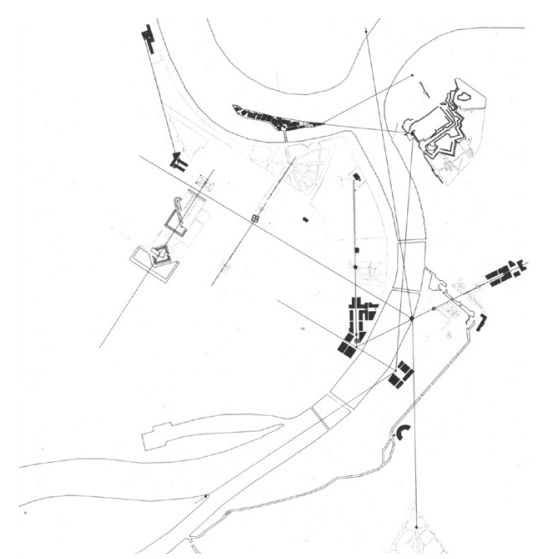

Figure 5 Miloš R. Perović and Branislav Stojanović, Study for the Reconstruction of the Central Part of New Belgrade and Sava Amphitheatre, focal points, 1985
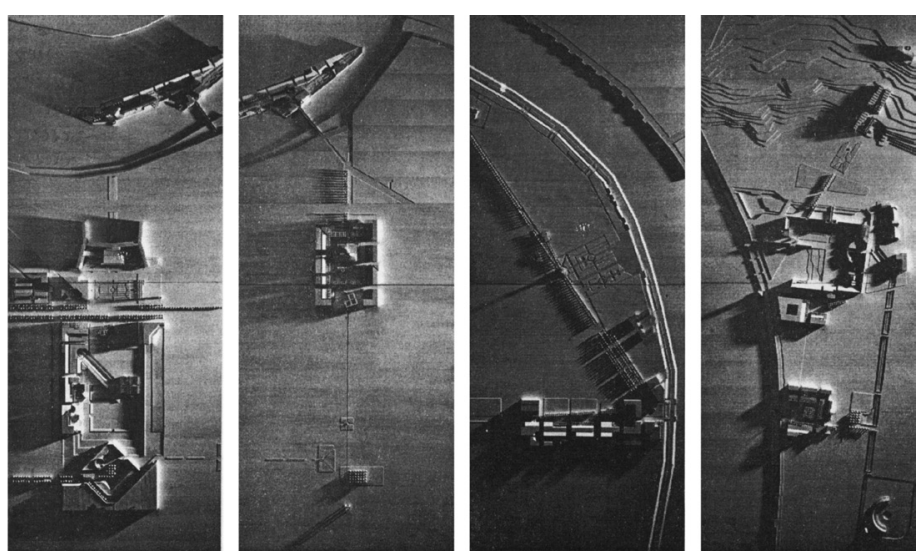
Furthermore, Belgrade's '"central position between the East and the West" was presumed as a basis of a "historical chance" ${ }^{125}$ for an achievement of unique results in the formation of a new, global culture. What the project explicitly included, under the guise of a global process, was the promotion of national (as in Serbian) culture, while the publication itself captured an "impossible gaze" 126 into the origins of culture and heritage, from the definitions of "our" (as in Serbian) "science's foundations" to the nostalgia for the times "when we were the cultural center of the world" 127 .

The entire project was marked by a vision of Serbia's backwardness, while the project itself was supposed to provide "spontaneous acceptance of innovations and shrinking of technological and cultural gap" 128 between Serbia and the rest of the developed, i.e. western world. The perception of the West as longue durée was confronted with the tragic history of Serbia, a country 'cut off from the rest of civilized world" 129 through the actions of a series of "enjoyment thieves" 130 , from the Turkish occupiers to the destroyers of Belgrade. The entire publication can in that sense, be seen as a form of nationalism without a clear political agenda, or as striving toward regeneration of national culture after decades of "lethargy and decline" 131 .

Formulated on the basis of an interview with "seventy-or so public workers, artists, scientists and cultural institutions managers" 132 the project program implied the construction of: new buildings of culture, buildings for the institutions that do not have adequate working conditions, a legacy pavilion, Information center, etc. The project exhibition included the designs for eleven new museums, a number of other buildings dedicated to culture, and a number of business, trade and hotel buildings ${ }^{133}$.

What is certainly clear is that the entire project for the new cultural center found its role model in the Paris projects from the 1970s and 1980s. The Pompidou Centre ${ }^{134}$, to which a text is dedicated within the publication ${ }^{135}$ was especially set aside as an example of a successful cultural renewal project. Also, the so-called Les Grands Travaux ${ }^{136}$, initiated by the French president François Mitterrand can be seen as part of a field that directed the project, while Perović himself interprets "the great and excellent presidential projects" as legacies of a "rich and centralized country such as France" $" 137$.

It can be claimed that the entire Središte kulture III milenijum project was defined on the basis of a real existence of a progressive and cultural West, which Serbia must "join" 138 . The entire project was directed toward the 
realization of progressive (national) tendencies, which in contact with Perović's account of a current loss of contact with contemporary urbanism, positioned the question of future urban development within the framework of an urban doctrine directly opposed to the tendency which was viewed as a basis of New Belgrade's existence.

In a way, this project can be seen, not as a result of an unquestionably clear view of the progressive West, but as a part of a fantasy dedicated to Serbian national future. The project implies the vision of technically and culturally dominant West, distanced from Serbia, whose position is conditioned by its tragic history. At the same time, the application of contemporary cultural center within New Belgrade and the Sava Amphitheatre is supposed to deliver the enjoyment which was taken away from Serbian culture by centuries of tragedy, and which is western as "in West more than West".

If we were to view the Središte kulture III milenijum publication as a hyperreal ${ }^{139}$ intervention, dedicated to the formation of focal points that can enable the mass consumption of culture ${ }^{140}$, or based on a series of urban forms torn from the social, political, or any other context ${ }^{141}$, or viewed through the sheer number of buildings proposed for construction at the time of Yugoslav economical crisis $^{142}$, we would miss a key aspect of the project. The project itself is more than a simple application of urban forms, it represents an attempt at acquiring the unfathomable $\mathrm{X}$, on at least three interconnected levels. Not only does it imply the acquisition of the transhistorical enjoyment of traditional urban structure, taken away by the "Le Corbusierian city", but it also implies the contemporary acquisition of enjoyment that originates in the fulfillment of a national project, viewed through the reality of West's existence, and securing the same enjoyment through the application of romanticist elements (which point to the "most valuable experience of repressed, but still vital national past" ${ }^{143}$ ) within the New Belgrade structure, erected by interventions that although "capable of following the contemporary European lines", are "more part of the world than Serbia and Belgrade" 144 .

What this attempt at triple acquisition of enjoyment demonstrates is how the architectural profession (or parts of it), moving through seemingly apolitical criticism of the theft of enjoyment by Le Corbusierian city, became part of a contemporary intervention dedicated to the national renewal project. It managed, by positioning itself as the element that "sticks out" (by it's contemporariness) in relation to the still current and out-dated practice of socialist urbanization, to help produce positive (unlike two previously described negative) visions of the West, in whose reflection the national future could be reviewed. 


\section{CONCLUSION}

The fantasies described in this paper point to the constant process of envisioning the Other, which, in the shape of the inner otherness, designates the acquisition of an excess that cannot be symbolized, i.e. the enjoyment. As such, the elimination or appropriation of this inner otherness becomes the foundation of one own identity.

The difference between the first two and the third fantasy can be viewed precisely in this context. While the first two cases imply the existence of the corrupt and decadent West that fits into the social fantasy space of Socialism itself, the third case implies the existence of the progressive West that fits into the social fantasy space of nationalism itself. The latter represents a testimony to the performative role of architectural profession, itself defined as enlightened and contemporary (consistently aware of the contemporary development of urbanism, as opposed to the current practices of socialist urbanization), in the formation of cultural versions of nationalism, the foundations of the "future politization of ethnicity" ${ }^{145}$.

What these fantasies have in common is a clear indication that the distinction between the contemporary and out-dated is nothing more that ideology itself, set to conceal that it is itself based on an illusion, an illusion of a clear and unquestionable gaze capable of attaining all of the reality of Other's existence, the gaze that guaranties the consistency of the desired social order. arhitekture Novog Beograda: period konceptualne faze od 1922. do 1962.godine (Doktorska disertacija, Univerzitet u Beogradu, Arhitektonski fakultet, 2004), 2. (JHA)) and socio-political organizations. See: Anonim, 'Deset godina Direkcije za izgradnju i rekonstrukciju Beograda," Izgradnja 12 (1976): 117-144 and Miodrag D Nikolić, "Usmerena stambena izgradnja i tržište stanova," Izgradnja 4 (1981): 3. propozicije konkursa (Beograd, Društvo arhitekata Beograda, 1985), 123. 
Zoran Manević, "Novija srpska arhitektura," U Srpska arhitektura 1900-1970, ur. Sovra Baračković, (Beograd: Muzej savremene umetnosti, 1972), 30.

Miloš R. Perović, Srpska arhitektura XX veka. Od istoricizma do drugog modernizma [Serbian $20^{\text {th }}$ Century Architecture. From Historicism to Second Modernism] (Belgrade: Faculty of Archtecture, 2003), 227.

To examine the parallels between the development of Serbian architecture during the 1990-s and the French architecture during the 1970-s and 1980-s, see: Perović, Srpska arhitektura, 218-229.

Zoran Manević treats the status of early 1950-s architecture as a question "of the abbility of Serbian architecture to follow the contemporary European avangarde lines"'. Miloš R. Perović expalines the relationship of the socialist settlement architects toward the evident world-wide tendency to criticize modern urbanism with the sentence: "'This critical approach was nonexistent for the architects" of socialist urbanisation. See: Manević, "Novija srpska arhitektura," 30. and Perović, Srpska arhitektura, 154.

The distinction is made by Miloš R. Perović between the principles of New Belgrade development during the 1960-s and 1970-s, which are defined as an application of "out-moded formulas of modernism", i.e. the examples of the "ideology of socialist estetism" and the "scientific" attempts at changing the urban paradigm in the period of 1970-s and 1980-s, which were based on the work of experts such as Jane Jacobs or Robert Krier. See: Miloš R Perović, Iskustva prošlosti (1985, Beograd: Plato, 2000), 78, 155. and Perović, Srpska arhitektura, 153.

Ljiljana Blagojević, "The Problematic of a "New Urban": The Right to New Belgrade," in Autogestion, or Henri Lefebvre in New Belgrade, ed. Sabine Bitter et al. (Berlin and Vancouver, Sternberg Press and Fillip Editions, 2009), 124.

On the definition of post-socialism, "as a proclamation of an end of socialism from within the socialism itself", see: Aleš Erjavec, introduction to Postmodernism and the Postsocialist Condition. Politicized Art under late Socialism, ed. Aleš Erjavec (Berkley, Los Angeles, London: University of California Press, 2003), 3.

Slavoj Žižek explains the fantasy, among his other definitions, as an "'element which sticks out", and as such, “'constitutes an identity of a field” See: Slavoj Žižek, Enjoy Your Simptom, (1992, New York and London: 2008), 103.

Slavoj Žižek. The Sublime object of Ideology (1989, London and New York: Verso, 2008.), 107. Žižek, Enjoy Your Simptom, 7.

Jacque Lacan., Ecrits. A Selection, trans. Alan Sheridan (1966, London and New York: Routledge, 2001), 300.

Žižek, Enjoy Your Simptom, 103.

Ibid., 52.

Edvard Kardelj, "Socijalistička demokracija u jugoslovenskoj praksi," u Edvard Kardelj. Socijalizam i demokracija, ur. Branko Caratan i Vjekoslav Mikecin (Zagreb: Globus, 1980), 131.

See: Manević, "Novija srpska arhitektura," 28.

Ibid, 28.

Anonim, "Deset godina Direkcije," 117-144.

Neven Šegvić, "Zablude i kriza buržoarske arhitekture,"Arhitektura (Zagreb) 13-17 (1948): 129131.

Ibid, 129

Ibid, 129-130.

Ibid, 130.

Šegvić places into under the term bourgeois architects a number of early 20th century architects, such as Walter Gropius, Mies Van de Rohe, and Le Courbusier. All of them are accused of submiting their work to the wishes of "upper clasess". See : Šegvić, "Zablude i kriza," 129-131. Ibid, 131 .

Ibid, 131.

Kazimir Ostrogović, "Arhitektura SSSR 1917-1947,' Arhitektura (Zagreb) 8-10 (1948): 5. 
Anonim, "Pokretanje revije Arhitektura." Arhitektura (Zagreb) 1 (1947): 3. The striving toward the elimination of capitalist remains also represents one of the few points of Branko Maksimović critical reproach to the article of Andrija Mohorovičić, which the Arhitektura editorial board didn't correct in its reproach to Maksimović article. The board corrected Maksimović in almost all of its key point, while insisting on the need for a "friendly critic" among the fighters for the new socialist architecture, but the vision of the existence of capitalist remains and the need for its elimination survived the editorial correction See: Andrija Mohorovičić, "'Teoretska analiza arhitektonskog oblikovanja," Arhitektura (Zagreb) 1-2 (1947): 5-8. and Anonim, "Napomene redakcije uz članak prof. Branka Maksimovića.” Arhitektura (Zagreb) 8-10 (1948): 76.

Branko Maksimović, "O teorijskom i naučnom radu u oblasti Sovjetske arhitekture," Arhitektura (Zagreb) 8-10 (1948): 15.

The competition was organized in 1947 in order to optain the designs for the Central Commity of the Communist Party headqarters and the Presidency of Federal Peoples Republic of Yugoslavia building, both on the territory of New Belgrade. See: Blagojević, Strategije modernizma, 41.

Josip Seissel, "Konkurs za urbanistiki plan Novog Beograda," Arhitektura (Zagreb) 3 (1947): 1822. This text is quated by Ljiljana Blagojević and viewed by the same author as a indication of a challenging of the social-realism paradigm by the Yugoslav architectural prffesion, during the late 1940-s. See: Blagojević, Strategije modernizma, 41. Mira Krajger, "Nekoliko misli o liniji naše arhitekture," Arhitektura (Zagreb) 13-17 (1948): 126130.

Ibid, 128.

Ibid, 128.

Ibid, 128

Milorad Macura, "Problematika naše arhitekture," Arhitektura (Zagreb) 3 (1947): 3-17.

Ibid, 3.

Macura, "Problematika naše arhitekture," 3.

Several building are named by Macura as exampels of decadent architecture, such as the Ministrerial building in Kneza Miloša Street and Postal Savings building. See: Macura, "Problematika naše arhitekture," 3-6.

Ibid, 6 .

This attitude can be seen in the light of that which Svetozar Stojanović defines as "normativistic projection of revolutionary goals into a socciety that has only begun to fullfill them". See: Svetozar Stojanović, Između ideala i stvarnoti ( Beograd: Prosveta, 1969), 17.

Blagojević, Strategije modernizma, 54.

A position might be defined as ideological, in the sense that it insists on the vision of architecture as a mere reflection of social processes. See: Fredric Jameson, ' 'On Interpretation: Literature as a Socially Symbolic Act," in The Jameson Reader, ed. Michael Hardt and Kathi Weeks (1981, Oxford: Blackwell, 2000), 41.

Žižek. The Sublime object, 107.

Neven Šegvić, 'Zablude i kriza," 130.

Macura, "Problematika naše arhitekture," 3.

Žižek, Enjoy Your Simptom, 103-104.

Jacques-Alain Miller, 'Extimité," in Lacanian Theory of Discourse. Subject, Structure and Society, ed. Mark Bracher, et al. (New York and London: New York University Press, 1994), 80. Jameson, "On Interpretation, 33-60.

On the information concerning the aquisition and export of western culural forms to the area of the Eastern block, see: Predrag Marković, Trajnost i promena. Društvena istorija socijalističke $i$ postsocijalističke svakodnevnice u Jugoslaviji i Srbiji (Beograd: Službeni glasnik, 2007), 42-49. 
Sharon Zukin, Beyond Marx and Tito. Theory and Practise in Yugoslav Socialism (1975, New York: Cambridge University Press, 2008), 48.

On the self-management as an "idea that is based on the philisophical principle of selfdetermination" and the realtion of self-determination to the "act of self-realisation of the subject, i.e. actualisation of basic human capacities and the satisfaction of true human needs ", see: Marković, 'Philosophical Foundations," 330.

Edvard Kardelj, 'O narodnoj demokratiji u Jugoslaviji," u Edvard Kardelj. Socijalizam i demokracija, ur. Branko Caratan i Vjekoslav Mikecin (Zagreb: Globus, 1980), 12.

Ljubomir Tadić, 'Order and Freedom," in Self-Governing Socialism, ed. Branko Horvat et al. (New York: International Arts and Sciences Press, 1975), 408.

Marković, "Philosophical Foundations," 349.

Ibid.

Uroš Martinović, “Arhitektura Srbije juče i danas," U 40 godina građevinartsva Socijalističke republike Srbije, ur. Miloš Jarić (Beograd: Izgradnja, 1987), 38-39. On the "contemporary architecture" as "less dogmatic than the architecture of the Modern movement", see: Bratislav Stojanović, "Urbanističko planiranje Novog Beograda-realizacije," Izgradnja 11-12 (1983), 12. See: Blagojević, Strategije modernizma, 53-64.

With the ratification of the 1960 Plan for the New Belgrade central zone, on the basis of the merging of two second-placed propositions from the из 1958-1959. competition, basic requirements were defined for the future development of New Belgrade. These plans will be marked by the 1980 -s critics of the New Belgrade urbanization as an example of the all that is presumably wrong in the development of New Belgrade. See: Aleksandar Đorđević, "Sistem i organizacija prostornog planiranja u Beogradu," Urbanizam Beograda 26 (1975): 3-10 and Miloš R. Perović, ed., Iskustva prošlosti [Lessons of the Past] (Belgrade: Zavod za planiranje razvoja grada [Institute for the Development Planning of the City of Belgrade], 1985), 123.

Đorđević, "Sistem i organizacija," 5.

Zoran Manević, ' Novi Resnik-jedna nada, jedna mogućnost," U Resnik-linearni grad-Avala grad. Katalog izložbe (Beograd: Kulturni centra Beograda, 1980), 41.

Among the projects that belong to this tendencion are the Cerak Vinogradi settlement, by Darko Marušić, Milenija Marušić and Nedeljko Borovnica, settlement Resnik-Avala Grad, by Aleksandar Đokić, and others. See: Milenija Marušić i Darko Marušić, "Cerak u 20 slika," u 40 godina građevinartsva Socijalističke republike Srbije, ur. Miloš Jarić (Beograd: Izgradnja, 1987): 127-136. and Aleksandar Đokić, ' Resnik-linearni grad-Avala grad," u Resnik-linearni grad-Avala grad. Katalog izložbe (Beograd: Kulturni centar Beograda, 1980): 7-32.

Ranko Radović, O arhitekturi (Beograd: Klub mladih arhitekata, 1971), 35.

Mihajlo Mitrović, "Savska građevina-"Staro Sajmište"," u Središte kulture III milenijum, ur. Stojan Ćelić (Beograd: SANU, 1985), 166.

Zoran Manević recognizes "natural contacts" of Resnik Avala-Grad plan with "our streets, from Kalemegdan to Slavija" just a few lines after he described "today's urban practise" as the "last remain of the state-bureaucratic ideal in our self-management community". See: Manević, "Novi Resnik," 41. and Aleksandar Ignjatović, "Poricanje i obnova: arhitektura postmodernizma 19801991," u Istorija umetnosti u Srbiji XX vek. Radikalne umetničke prakse, ur Miško Šuvaković (Beograd: Orion art, 2010), 667.

One of the first debate concerning the socialist city was initiated as early as 1964, on the page of Naše teme magazine, dedicated to the question of "urbanism outside socialism". See: Ognjen Čaldarović, "Sociologija i socijalistički grad," Naše teme 9 (1984): 1584-1599. See also: Nenad Starc, 'Socijalizam, gradovi i krize," Pogledi 4 (1985): 19.

Ibid.

Ibid.

Marjan Uzelac, "Ulomci, utopija i postmoderni urezi," Naše teme 1-3 (1987): 73.

Ognjen Čaldarović, “'Sociologija i socijalistički grad," 1587. 
Starc, "Socijalizam, gradovi ," 21.

Milorad Macura, ''Međuzavisnost reintegracije arhitektonskog prostora i samoupravnog socijalističkog razvoja," Arhitektura urbanizam 80-81 (1978): 49-50.

Ibid, 49.

Ibid.

Ibid.

Ibid.

Ibid, 50 .

Ibid.

Ibid.

Henri Lefebvre, 'Industrialisation and Urbanisation, ' in Writings on Cities / Henri Lefebvre, ed. Eleonore Kofman and Elizabeth Lebas (Oxford: Blackwell, 1996.), 75-80.

See also: Henri Lefebvre, 'Fragmentary Siences and Urban Reality," in Writings on Cities / Henri Lefebvre, ed. Eleonore Kofman and Elizabeth Lebas (Oxford: Blackwell, 1996.), 94-96.

Žižek. The Sublime object, 110, 143.

Ibid, 143.

Melita Richter, 'Socijalistički grad ili grad socijalizma," Naše teme 9 (1984), 1600.

Žižek. The Sublime object, 50.

On the concept of strugle in the context of Yugoslav socialism: Zukin, Beyond Marx and Tito, 218-221.

Blagojević, "The Problematic", 124.

Dušica Seferagić i Vladmir-Braco Mušić. “'Kamo ide naš urbanizma." Naše teme 1-3 (1987): 48. As in architect that, during the first decades of socialism treated the doctrine of the Modern movement as adequate to the goals of socialism.

Blagojević, Strategije modernizma, 12.

Boris Grojs, Stil Staljin, prev. Dobrilo Aranitović (1993, Beograd: Službeni glasnik, 2009), 40. Ksenija Petovar, "Uticaj političkog faktora na planiranje i izgradnju grada." Naše teme 13 (1987): 56.

Ibid, 61.

Perović, ed., Iskustva prošlosti.

Ibid, 126.

Ibid, 43-44.

Ibid, 141.

Ibid, 126.

See: Blagojević, Strategije modernizma, 31-50.

This division, according to Miloš Perović is paralel to the division of the CIAM delegates on the dogmatic and progresive line, during the Aix-en Provence Congress, held in 1953. See: Perović, ed., Iskustva prošlosti, 126.

Ibid, 125.

Perović, ed., Iskustva prošlosti, 134.

On the connection between CIAM and Delos see: Miloš R. Perović, Pogovori z delosovci [Dialogues with the Delians] (Ljubljana: Sinteza, 1978): 129.

Dimitrije Mladenović, "Povelja "'Machu Picchu"," Arhitektura urbanizam 82 (1979): 49.

Anonim, "Da li je "Atinska povelja" prevaziđena "Deklaracijom arhitekata sveta 1981"," Arhitektura urbanizam 86/87 (1981): 8.

Ranko Radović, "Skica za jednu temeljnu kritiku i praksu modernog urbanizma," Arhitekturaurbanizam 86/87 (1978): 25.

Ibid, 40.

Ranko Radović, "Od kritike modernog urbanizma do sopstvene radne filozofije i prakse ljudskih naselja naše sredine," Urbanizam Beograda 62 (1981): 43.

The general place of the New Belgrade and socialist urbanisation criticism during the 1970-s and 
1980-s was the belief that that the same were a result of an implementation of foreign elements, which were seen as a copycated into Yugoslav context. The diversification of these approaches was conducted through the question of the way one's own response should be defined, while the question of selfness was slowly shifted from Yugoslav and socialist perspective to the Serbian and nationalist focus. See: Ignjatović, "Poricanje i obnova," 666. и Marin Krešić, "Dve istraživačke studije posvećene novom gledanju na Beograd," Arhitektura urbanizam 93 (1984): 33.

Perović, ed., Iskustva prošlosti, 155.

Ibid, 161.

On the New Blegrade side of the city there are three main focal points. From the river square a direction is developed toward the focal point of the Staro Sajmište tower, and form here a direction is developed toward the Muzej Savreme Umetnosti building. See: Perović, ed., Iskustva prošlosti, 161.

Ibid, 168.

Bulevar Lenjina is considered for the transformation into a "city boulevard, with paved streets, double treelines and solid building front". The placement of central functions is arranged throughout the Španskih Boraca, Bulevar AVNOJ-a, and Milentija Popovića streets. The rest of the urban tissue is defined as a "colorfull comlement of existing structures, comprised of the elements of the traditional town... These elements have precise social and physical dimensions and a great complexity of functions compared to the monotonous zoning of functionalistic town plaanning". See: Perović, ed., Iskustva prošlosti, 169.

Ibid, 171.

The authors of architectural solutions are named in the publication. See: Stojan Ćelić, ur. Središte kulture III milenijum (Beograd: SANU, 1985), 149.

Quatted in: Aleksandar Despić, "U susret III milenijumu," u Središte kulture III milenijum, ur. Stojan Ćelić (Beograd: SANU, 1985), 7.

Ibid, 7.

Žižek, For They Know Not What They Do. Enjoyment as a Political Factor (1991, London and New York: Verso, 2008), 197.

See: Milorad Mlađenović, "Temelji naše nauke," u Središte kulture III milenijum, ur Stojan Ćelić (Beograd: SANU, 1985), 15. and Dragoslav Srejović, "Kad smo bili kulturno središte sveta," u Središte kulture III milenijum, ur. Stojan Ćelić (Beograd: SANU, 1985), 41.

Miloš R. Perović, 'Središte kulture III milenijum: urbanološki koncept," U Središte kulture III milenijum, ur. Stojan Ćelić (Beograd: SANU, 1985), 89.

Quatted in: Despić, "U susret III milenijumu," 7.

Žižek, For They Know ,182-188.

For the information on the nation an nationalism in the context of cultural and plitical content, see: Anthony D. Smith. The Cultural Foundations of Nations. Hierarchy, Covenan and Republic (Oxford: Blackwell Publishing, 2008), 24-27.

Petar Ignjatović, "III milenijum-mišljenja o kulturnom središtu," u Središte kulture III milenijum, ur. Stojan Ćelić (Beograd: SANU, 1985), 127.

The exhibition was formed by the projects for the: Museum of Inventions, Railways Museum, Museum of Postal Services, Archeological Museum, Museum of Academies, Museum of Man, Museum of Paradox, Museum of Culture, museum of Literature, Sociological Museum Museum of Natural History. The exhibition was also formed by projects for the: Information Centre, Open University, Concert Hall, Belgrade Town Library, Musical Academie, Centre for the Study of Other Civilizations, Opera House, Galleria Obscura, and a number of projects for hotels, housing and business buildings, shopping centres, etc. See: Ćelić, ur. Središte kulture, 149. Centre Georges Pompidou was opened in 1977, and named after the current French president. 
Mitterrand, who, along with several closest collegues made the most of the decisions concerning the design competitions, including the selection of finning proposals. See: Ronald Tiersky, François Mitterrand. A Very French President (2000, Lanham, MR: Rowman \& Littlefield Publishers, 2003), 257.

Miloš R Perović, Iskustva prošlosti (1985, Beograd: Plato, 2000), 204.

Quatted in: Despić, "U susret III milenijumu," 8.

As in the meaning of the term used by Mihail Epstain, i.e. as an example of a West that doesnt exist in the West itself. See: Mihail Epštajn, Postmodernizam, prev. Radmila Mečanin (1995, Beograd: Zepter Book World, 1998), 47.

Focal points can be seen as an element that enables the average user to orient himself within the new urban structure, guarrantiing the mass consumption of new architectural and urban interventions. Also one should be aware that as a sinonim for the succses of Beaubourg project, the visitor statistics are named within the publication. See: Rosandić, "Kulturni centri," 135-139. On should remember here that the effect of new interventions are compared by the author with walking through the Classical French gardens, or the quoted confrontation of the political context with the basic human need.

It is indicative that the than current economiccal crisis is viewed by the authors of the publication simply as a positive condition. See: Despić, "U susret III milenijumu," 9. On the data concerning the foreign depts of Yugoslavia and the economical crissis of the 1970-s and 1980-s, see: Marković, Trajnost i promena, 17.

Ignjatović, "Poricanje i obnova," 667.

Manević, "Novija srpska arhitektura," 33.

Smith, Cultural Foundations of Nation, 27.

Anonim. "Da li je "Atinska povelja" prevaziđena "Deklaracijom arhitekata sveta 1981"." Arhitektura urbanizam 86/87 (1981): 8.

Anonim. "Deset godina Direkcije za izgradnju i rekonstrukciju Beograda." Izgradnja 12 (1976): 117-144.

Anonim. "Zavod za planiranje razvoja grada Beograda." Izgradnja 7 (1979): 48-52.

Anonim. 'Pokretanje revije Arhitektura." Arhitektura (Zagreb) 1 (1947): 3.

Anonim. 'Napomene redakcije uz članak prof. Branka Maksimovića." Arhitektura (Zagreb) 8-10 (1948): 76-80.

Blagojević, Ljiljana. Strategije modernizma u planiranju i projektovanju urbane strukture $i$ arhitekture Novog Beograda: period konceptualne faze od 1922. do 1962.godine. Doktorska disertacija. Univerzitet u Beogradu, Arhitektonski fakultet, 2004.

Blagojević, Ljiljana. "The Problematic of a "New Urban": The Right to New Belgrade." In Autogestion, or Henri Lefebvre in New Belgrade, edited by Sabine Bitter and Helmut Weber, 119-134. Berlin and Vancouver: Sternberg Press and Fillip Editions, 2009.

Čaldarović, Ognjen. "Socijalizam i grad." Pogledi 4 (1985): 5-17.

Despić, Aleksandar. "'U susret III milenijumu." U Središte kulture III milenijum, urednik Stojan 
Ćelić, 9-23. Beograd: SANU, 1985.

Đokić, Aleksandar. "'Resnik-linearni grad-Avala grad." U Resnik-linearni grad-Avala grad. Katalog izložbe, 7- 32. Beograd: Kulturni centar Beograda, 1980.

Đorđević, Aleksandar. "'Sistem i organizacija prostornog planiranja u Beogradu." Urbanizam Beograda 26 (1975): 3-27.

Đorđević, Aleksandar. 'Urbanističko rešenje centralnog dela Novog Beograda." Arhitektura urbanizam 2 (1960): 3-10.

Epštajn, Mihail. Postmodernizam (1995). Prevod: Radmila Mečanin. Beograd: Zepter Book World, 1998.

Erjavec, Aleš. Introduction to Postmodernism and the Postsocialist Condition: Politicized Art under Late Socialism, edited by Aleš Erjavec, 1-54. Berkley and Los Angeles: University of California Press, 2003.

Grojs, Boris. Stil Staljin (1993). Prevod Dobrilo Aranitović. Beograd: Službeni glasnik, 2009.

Ignjatović, Aleksandar. 'Poricanje i obnova: arhitektura postmodernizma 1980-1991." U Istorija umetnosti u Srbiji XX vek. Radikalne umetničke prakse, urednik Miško Šuvaković. 663-671. Beograd: Orion art, 2010.

Ignjatović, Petar. 'III milenijum-mišljenja o kulturnom središtu." U Središte kulture III milenijum, urednik Stojan Ćelić, 131-138. Beograd: SANU, 1985.

Jameson, Fredric. ' On Interpretation: Literature as a Socially Symbolic Act" in The Jameson Reader, edited by Michael Hardt and Kathi Weeks, 33-60. Oxford: Blackwell, 2000.

Kadijević, Aleksandar. Mihajlo Mitrović. Projekti, graditeljski život, ideje. Beograd: Nezavisna izdanja Slobodana Mašića, Muzej nauke i tehnike, Muzej arhitekture, 1999.

Kardelj, Edvard. 'O narodnoj demokratiji u Jugoslaviji." U Edvard Kardelj. Socijalizma $i$ demokracija, urednici Branko Caratan i Vjekoslav Mikecin, 1-38. Zagreb: Globus, 1980.

Kardelj, Edvard. 'Nacionalno pitanje i socijalizam.” U Edvard Kardelj. Socijalizma i demokracija, urednici Branko Caratan i Vjekoslav Mikecin, 317-340. Zagreb: Globus, 1980.

Kardelj, Edvard. 'Neki problemi kulturno-prosvjetne politike." U Edvard Kardelj. Socijalizma i demokracija, urednici Branko Caratan i Vjekoslav Mikecin, 107-123. Zagreb: Globus, 1980.

Kardelj, Edvard. 'Socijalistička demokracija u jugoslovenskoj praksi." U Edvard Kardelj. Socijalizma i demokracija, urednici Branko Caratan i Vjekoslav Mikecin, 131-171. Zagreb: Globus, 1980.

Krajger, Mira. 'Nekoliko misli o liniji naše arhitekture.” Arhitektura 13-17 (1948): 126-130.

Krešić, Marin. 'Dve istraživačke studije posvećene novom gledanju na Beograd." Arhitektura urbanizam 93 (1984): 33-34.

Lacan, Jacque. Ecrits. A Selection. Translation by Alan Sheridan (1966). London, New York: Routledge, 2001

Lefebvre, Henri. "Industrialisation and Urbanisation." In Writings on Cities / Henri Lefebvre, edited by Eleonore Kofman and Elizabeth Lebas, 75-80. Oxford: Blackwell, 1996.

Lefebvre, Henri. "Fragmentary Siences and Urban Reality." In Writings on Cities / Henri Lefebvre, edited by Eleonore Kofman and Elizabeth Lebas, 94-96. Oxford: Blackwell, 1996.

Maksimović, Branko. 'O teorijskom i naučnom radu u oblasti Sovjetske arhitekture.” Arhitektura (Zagreb) 8-10 (1948): 15-16.

Marković, Predrag. Trajnost i promena. Društvena istorija socijalističke i postsocijalističke svakodnevnice u Jugoslaviji i Srbiji. Beograd: Službeni glasnik, 2007.

Manević, Zoran. 'Novi Resnik-jedna nada, jedna mogućnost." U Resnik-linearni grad-Avala grad. Katalog izložbe, 40-41. Beograd: Kulturni centra Beograda, 1980.

Manević, Zoran. "Novija srpska arhitektura." U Srpska arhitektura 1900-1970, urednik Sovra Baračković, 7-38. Beograd: Muzej savremene umetnosti, 1972.

Marković, Mihailo. "Philosophical Foundations of the Idea of Self-management." In SelfGoverning Socialism, edited by Branko Horvat, Mihajlo Marković and Rudi Šupek, 327-350. New York: International Arts and Sciences Press, 1975. 
Martinović, Uroš. "Arhitektura Srbije juče i danas." U 40 godina građevinartsva Socijalističke republike Srbije, urednik Miloš Jarić, 31-40. Beograd: Izgradnja, 1987.

Marušić, Milenija i Darko Marušić. "Cerak u 20 slika." U 40 godina građevinartsva Socijalističke republike Srbije, urednik Miloš Jarić, 127-136. Beograd: Izgradnja, 1987.

Macura, Milorad. "Međuzavisnost reintegracije arhitektonskog prostora i samoupravnog socijalističkog razvoja." Arhitektura urbanizam 80-81 (1978): 49-50.

Macura, Milorad. "Problematika naše arhitekture." Arhitektura (Zagreb) 3 (1947): 3-17.

Miller, Jacques-Alain. "Extimité." In Lacanian Theory of Discourse. Subject, Structure and Society, edited by Mark Bracher, Marshall W. Alcorn, Jr., Ronald J. Corthell and Françoise Massardier-Kenney, 74-87. New York nad London: New York University Press, 1994

Mitrović, Mihajlo. ,'Savska građevina-"Staro Sajmište"." U Središte kulture III milenijum, urednik Stojan Ćelić, 165-167. Beograd: SANU, 1985.

Mladenović, Dimitrije. ,'Povelja ,'Machu Picchu"." Arhitektura urbanizam 82 (1979): 49.

Mlađenović, Milorad. ,'Temelji naše nauke." U Središte kulture III milenijum, urednik Stojan Ćelić, 15-23. Beograd: SANU, 1985.

Mohorovičić, Andrija. ,'Teoretska analiza arhitektonskog oblikovanja." Arhitektura (Zagreb) 1-2 (1947): 5-8.

Nikolić, Miodrag D. ,'Usmerena stambena izgradnja i tržište stanova.” Izgradnja 4 (1981): 3-8.

Ostrogović, Kazimir. ,'Arhitektura SSSR-a 1917-1947." Arhitektura (Zagreb) 8-10 (1948): 3-8.

Perović, Miloš R. Iskustva prošlosti (1985). Beograd: Plato, 2000.

Perović, Miloš R. ed., Iskustva prošlosti [Lessons of the Past]. Belgrade: Zavod za planiranje razvoja grada [Institute for the Development Planning of the City of Belgrade], 1985.

Perović, Miloš R. Pogovori z delosovci [Dialogues with the Delians]. Ljubljana: Sinteza, 1978.

Perović, Miloš R. 'Središte kulture III milenijum: urbanološki koncept." U Središte kulture III milenijum, urednik. Stojan Ćelić, 89-119. Beograd: SANU, 1985.

Perović, Miloš R. Srpska arhitektura XX veka. Od istoricizma do drugog modernizma [Serbian 20th Century Architecture. From Historicism to Second Modernism]. Belgrade: Faculty of Archtecture, 2003.

Petovar, Ksenija. 'Socijalni prostor Novog Beograda." U Budućnost Novog Beograda: Raspis $i$ propozicije konkursa, 121-124. Beograd, Društvo arhitekata Beograda, 1985.

Petovar, Ksenija. 'Uticaj političkog faktora na planiranje i izgradnju grada." Naše teme 13 (1987): 55-64.

Radović, Ranko. 'Od kritike modernog urbanizma do sopstvene radne filozofije i prakse ljudskih naselja naše sredine." Urbanizam Beograda 62 (1981): 40-47.

Radović, Ranko. O arhitekturi. Beograd: Klub mladih arhitekata, 1971.

Radović, Ranko. 'Skica za jednu temeljnu kritiku i praksu modernog urbanizma.," Arhitekturaurbanizam 86/87 (1978): 18-25.

Richter, Melita. 'Socijalistički grad ili grad socijalizma." Naše teme 9 (1984): 1600-1608.

Rosandić, Ružica. ''Kulturni centri u svetu”. U Središte kulture III milenijum, urednik Stojan Ćelić, 135-139. Beograd: SANU, 1985.

Seissel, Josip. 'Konkurs za urbanistiki plan Novog Beograda." Arhitektura (Zagreb) 3 (1947): 18-22.

Seferagić, Dušica i Vladmir-Braco Mušić. "Kamo ide naš urbanizma.” Naše teme 1-3 (1987): 40-54.

Srejović, Dragoslav. "Kad smo bili kulturno središte sveta." U Središte kulture III milenijum, urednik Stojan Ćelić, 41-67. Beograd: SANU, 1985.

Smith, Anthony D. The Cultural Foundations of Nations. Hierarchy, Covenan and Republic. Malden, Oxford, Carlton: Blackwell Publishing, 2008

Starc, Nenad. 'Socijalizam, gradovi i krize." Pogledi 4 (1985): 18-25.

Stojanović, Bratislav. "Urbanističko planiranje Novog Beograda-realizacije." Izgradnja 11-12

(1983): 12-24 
Stojanović, Svetozar. Između ideala i stvarnoti. Beograd: Prosveta, 1969.

Tadić, Ljubomir. 'Order and Freedom.” In Self-Governing Socialism, edited by Branko Horvat, Mihajlo Marković and Rudi Šupek, 405-415. New York: International Arts and Sciences Press, 1975.

Tiersky, Ronald . François Mitterrand. A Very French President (2000). Lanham, MR: Rowman \& Littlefield Publishers, 2003.

Uzelac, Marjan. 'Ulomci, utopija i postmoderni urezi.” Naše teme 1-3 (1987): 65-82.

Uzelac, Marjan. “'Sociologija i socijalistički grad.” Naše teme 9 (1984): 1584-1599.

Šegvić, Neven. ' Zablude i kriza buržoarske arhitekture.” Arhitektura (Zagreb) 13-17 (1948): 129131.

Žižek, Slavoj. Enjoy Your Simptom (1992). New York and London: Routledge, 2008

Žižek, Slavoj. Sublime object of Ideology (1989). London and New York: Verso, 2008.

Žižek, Slavoj. For They Know Not What They Do. Enjoyment as a Political Factor (1991). London and New York: Verso, 2008.

Zukin, Sharon. Beyond Marx and Tito. Theory and Practise in Yugoslav Socialism (1975). New York. Cambridge University Press, 2008. 